\title{
Development of Leaning Management Model for Creative and Innovation Skills Enhancement of Primary Students: A Case Study in Thailand
}

Marut Patphol, Srinakharinwirot University, rutmarut@gmail.com, ORCID: 0000-0002-8627-7670

Wichai Wongyai, Srinakharinwirot University, wongyaiwed@gmail.com, ORCID: 0000-0002-8453-4186

\begin{abstract}
The objectives of this research were to develop and assess the effectiveness of the learning management model for creative and innovation skills enhancement. Target group was 14 Prathomsuksa 5 students. The AB design plan was used for the trial. Holistic scoring rubrics criteria was applied to the data collection. Research result indicated that the developed model based on the progressivism and constructivism which the learning process comprised of 3 steps including the work principle of King Rama IX, "Understanding", "Access" and "Develop". The model was called "UAcD model" which was the learning management model that emphasized on the process as the content (content free). The "UAcD" model based on constructivism theory and continuous development cycle. The evaluation result of the model effectiveness showed that the students creative and innovation skills increased throughout the evaluation period during the model implementation, which qualified the criteria.
\end{abstract}

Keywords: Creative and Innovation Skill, Model of Learning Management, Primary Student

Received: 23.03.2020 Accepted: 02.08.2020 Published:

\section{INTRODUCTION}

In the future, the world will be totally different due to technology advancement which results in the economic adjustment and more application of technology in businesses. Consequently, the demand for the non-creative labor is likely to decrease dramatically (World Economic Forum, 2018; OECD, 2018a; OECD, 2018b) and be replaced with robotics and artificial intelligence (World Economic Forum, 2016).

Such context urges schools to adapt the teaching and learning management to prepare the students before entering the new different world of work (World Economic Forum, 2018). Students require the development of creative and innovation skills (OECD, 2018b) which the 3 key components are creative thinking, creative collaboration and successful innovation creativity (Partnership for 21st Century Skills. 2011, Nieuwerbugh, 2017; OECD, 2018b).

The creative and innovation skills consist of 3 components which are 1) think creatively consist of Initiative, use a variety of thinking processes, positive thinking, flexible thinking, modify thinking 2) work creatively with others consist of work with others and responsibilities, listen to others' opinions, collaborative, respect the rules, sharing idea, and accountability and 3) implement and improve for innovation consist of planning, design the innovation, implementation, and effectiveness evaluation (Williams. 1969, Torrance. 1977, Guilford. 1988, Anderson and Krathwohl. 2001, Department of Education, Employment and Workplace Relations. 2009, Griffith University. 2011, Partnership for 21 $1^{\text {st }}$ century skills. 2011).

Reinforcement of students creative and innovation skills is very crucial to taking in to consideration (UNESCO, 2018). The ideal approach is to start the process from the early year by making the development and the learning management concurrently to be consistent with the students' way of life (OECD, 2018b) via learning by doing and the efficient learning activities designed by the teacher. Learning is the result of the student practice. The teacher roles are to encourage and support the student to apply the learning and thinking process to accomplish the learning and to utilize the learning process to construct the potential learning (Abdulla, 2017; Sweeney, \& Mausbach, 2018). It is in line with the progressivism, which believes that all learners are able to learn and develop if they carry out the activities appropriately (Dewey, 1934), and the 
constructivism, which the goal is to allow the learners to construct knowledge by themselves (Hein, 1991). Moreover, it is in accordance with the work principle of King Rama IX, "Understanding", "Access" and "Develop", which is applied to develop the successful innovations globally (Thailand Sustainable Development Foundation, 2018).

Learning management that enhances creative and innovative skills, using studentoriented learning management practices (Hondzel. 2013) through Problem-Based Learning (PBL), Project-Based Learning (ProBL) (Bell. 2010, Rotherham and Willingham. 2010), and others active learning methods (McGinn. 2007). In addition, the enhancing principles of creative and innovation skills including 1) learning design relevant with the students' lifestyle 2) encourage students to use thinking processes 3) develop basic thinking skills and high-order thinking skills 4) encourage students to transfer learning 5) develop learning process skills 6) correct the students' mistakes 7) use the collaborative learning process 8) use technology for learning support and 9) stimulate the students' creativity (Saavedra and Opfer. 2012). Also, teachers should set the atmosphere for learning to be challenging, independent, and supportive and instructors provide ongoing student support (Adams. 2005).

In past decade, the study relevant learning management model for enhancing creative and innovation skills found that creative and innovation skills can be developed by architectural workshops (Sadykova, Semenyuk, Khvan, \& Kuc. 2016), using mind mapping (Miranti, \& Wilujeng. 2017), using a variety of stimulating ideas to find possible solutions to the problems facilitates brainstorming and helps learners think about new ideas also using questions, classroom discussion, self-directed study, inductive and deductive thinking, media or social media make students engage in learning activities and create innovation in learning (Seechaliao. 2017). Using a Cognitive-Based Creativity Training (Ritter \& Mostert. 2017), using STEM model for instruction (Rahmawati, Ridwan, Hadinugrahaningsih, \& Soeprijanto. 2018).

Although there are many researches that develop creative and innovation skills as mentioned above, however lack of research on the development of learning management model for creative and innovation skills enhancement of the primary students that suits the students' way of life and the need for the development of creative and innovation skills of primary students, the researcher developed the learning management model for creative and innovation skills enhancement of the benefits of further application.

The researcher applied the constructivism theory and the continuous improvement cycle "Plan Do Check Reflect" for developing a learning management model according to the figure 1. and also, the objectives of this research were to develop and assess the effectiveness of the learning management model for creative and innovation skills enhancement.

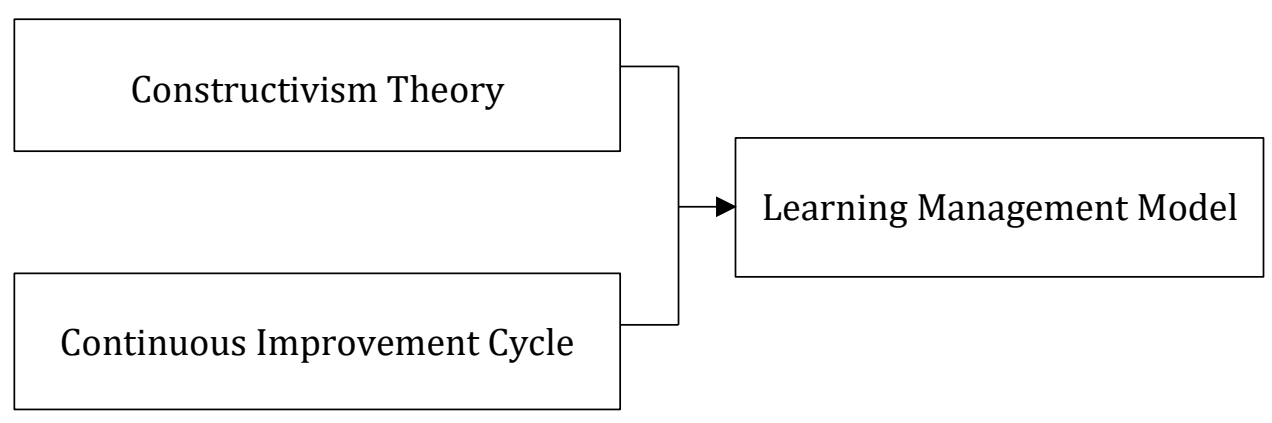

Figure 1. Conceptual Framework 


\section{METHODS}

The development of learning management model for creative and innovation skills enhancement comprised of 4 steps following the research and development method, and also this research has been accepted by the Human Research Ethics Committee of Srinakharinwirot University, Thailand.

Step 1 The study on primary information of the development of learning management model. The aims were to examine the guideline for learning management enhancing creative and innovation skills and to investigate the teacher opinion towards the learning management enhancing creative and innovation skills. All relevant documents to an educational philosophy, work principles of King Rama IX, learning theories, creative and innovation skills in the 21st Century, authentic assessment, and learning management for creative and innovation skills enhancement were synthesized. Further, 4 elementary schools' administrators and 28 elementary schools' teachers selected by purposive selection were interviewed using the semistructure interview about creative and innovation enhancing for elementary students that created by the researcher. The researcher conducted the interview and analyzed the results by using content analysis.

Step 2 Design of learning management model. After having the conclusion from step 1, the researcher designed a first draft of learning management model for creative and innovation skills enhancement. The draft based on the progressivism, which believed that everyone was able to learn and develop from learning by doing and accumulate the experiences (Dewey, 1934), the work principle of King Rama IX, which included "Understanding", "Access" and "Develop", and constructivism, which encouraged the student to apply the learning process and knowledge by themselves (Hein, 1991). Learning management model consisted of principle, purpose, learning management process, and learning measurement and evaluation. Then, the quality of consistency, appropriateness and probability was tested by 5 experts in elementary education field. A five level of rating scales (highest, high, moderate, low, lowest) was used for checking the quality of learning management model. It was composed of 3 dimensions 1) consistency, 2) appropriateness and 3) probability. Gathering the data by presentation the learning management model to the experts and then the expert evaluated the consistency, appropriateness and probability using the rating scale. The results indicated that the consistency, appropriateness and probability was at the highest (mean $=4.65, \mathrm{SD}=0.32$ Total score=5.00). The model implementation was tried out in December 2017 to 12 Prathomsuksa 5 students in Suphan Buri province. The trial results showed that the student creative and innovation skills after model implementation was higher than that before the implementation (before implementation mean=12.50 SD.=2.42, after implementation mean=21.28 SD.=1.75,). The model was improved and revised, as the third draft, before implementing with the sample group.

Step 3 Implementation of the learning management model. The researcher implemented the learning management model to the targeted students by using The $\mathrm{AB}$ design (Levin, Marascuilo \& Hubert, 1978). Gathering the data before implementation for twice times, during implementation 4 times, and after implementation twice times. There were 14 elementary students in Suphan Buri province, Thailand were selected by multi-stage sampling. Data was collected by the teachers and the researcher and observed the students' behavior during doing the creative activities. Data was collected twice every 2 weeks before the implementation, 4 times every 2 weeks during the implementation, and twice every 2 weeks after implementation. The 5 items of holistic scoring rubrics criteria were applied and the evaluation results were classified into 5 levels: Have self-reliant and assist other (5), Have self-reliant (4), Have self-reliant with advices (3), Follow the model and example (2), and Perform when having assistance (1). Total score was 25 . The reliability of the holistic scoring rubrics was 0.87 . The researchers conducted learning management model in the classroom by using an active learning approach through creative-based activities. There were created innovations relevant to the environmental protection, waste reducing following the Plan Do Check Reflect procedure. 
Step 4 Evaluation of the learning management model effectiveness which was conducted in April 2018 after the implementation of the learning management model. The researcher evaluated the effectiveness of the model by using the effectiveness criteria "the student creative and innovation after model implementation higher than before. The summary of research methodology was shown as the following chart.

Step

\begin{tabular}{|c|}
\hline Step 1 \\
Study on primary \\
information of the \\
development of \\
learning \\
management model
\end{tabular}

1. Study the guidelines for learning management for creative and innovation skills enhancement.

2. Study the opinions of the teachers towards the learning management for creative and innovation skills enhancement.

\begin{tabular}{|c|c|}
\hline & \\
\hline $\begin{array}{l}\text { Step } 2 \\
\text { Design of learning } \\
\text { management model }\end{array}$ & $\begin{array}{l}\text { 1. Design the learning management model based on } \\
\text { the progressivism, constructivism and work principle, } \\
\text { "Understanding", "Access" and "Develop". } \\
\text { 2. Tried out the model. }\end{array}$ \\
\hline & 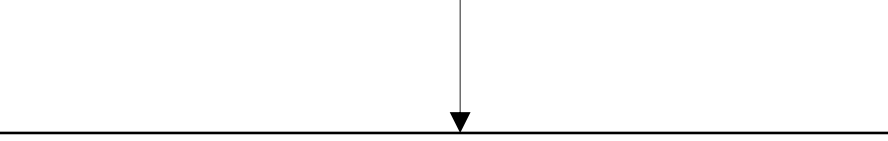 \\
\hline $\begin{array}{l}\text { Step } 3 \\
\text { Implementation of } \\
\text { the model }\end{array}$ & $\begin{array}{l}\text { 1. Tried out the model with the targeted students. } \\
\text { 2. Collect data using The AB design (Levin, Marascuilo } \\
\text { \& Hubert. 1978). }\end{array}$ \\
\hline & \\
\hline $\begin{array}{l}\text { Step } 4 \\
\text { Evaluation of the } \\
\text { learning } \\
\text { management model } \\
\text { effectiveness }\end{array}$ & $\begin{array}{l}\text { 1. Evaluate the model effectiveness followed the } \\
\text { criteria. } \\
\text { 2. Revised the model. }\end{array}$ \\
\hline
\end{tabular}

FIGURE 2. Research methodology 


\section{RESULTS}

\section{Development result of the learning management model for creative and innovation skills enhancement}

The results of model implementation showed that the model was founded on the progressivism which believed that the students could have the self-learning via the learning activities that fulfilled their demand and interest.

Moreover, the model was founded on the constructivism which aimed to develop the students via learning by doing to construct the experience to further the learning. The teacher encouraged, promoted and supported the students by asking questions, evaluating and providing useful feedback for the learning development of the student.

Further, the work principle of King Rama IX comprising "Understanding”, "Access" and "Develop", was adapted as the key foundation of the learning management model design. For this reason, the model was the process as the content (content free).

Teacher was able to adapt it to the learning activities related to the problemsolving in a daily basis at school, home or in the community. The student would look for the solution that connected to the knowledge of each subject or other relevant knowledge. Such solution contained 3 features of innovation, which were novelty, utility and requirement of the other. The application of learning management model was flexible to period, including the normal learning management, learner development activities or activities to minimize the learning time and maximize the knowing time.

The discovered learning management model for creative and innovation enhancement from this research was "UAcD" model which combined the first initial letter of the learning process in the model (Ac stand for Access). The components were concept, objective, learning process, media and learning source, and evaluation and feedback. The essence of each component was as follows.

\section{1) Concept}

Creative and innovation skills are the crucial skill for the current world. Therefore, the learning management should develop the learner to construct the creative and innovation skills to have a potential for the future career.

\section{2) Objective}

To enhance the student creative and innovation of skills.

\section{3) Learning process}

Learning process of the learning management model for creative and innovation skills enhancement consisted of 3 steps which the complexity was flexible based on the learner as follows.

Step 1 Understanding. To encourage learner to observe the surrounding problems which were at the individual, classroom and school, or the community level, such as problem of dealing with homework, classroom environment, resource usage in classroom, and waste management in school. Then, the learner analyzed the cause or the system of problem (applying the systematic thinking), how the problem had the effect on other things, the disadvantages of the problem existence or the benefits after the problem was resolved.

After the problem analysis, the learner evaluated their potential to resolve such problem by themselves (if it was the individual problem) or cooperate to find the solution (if it was the classroom, school or community problem) and make decision to resolve problem using the innovation creation process.

Step 2 Access. To encourage the learner to pursue knowledge to design the solution by using the 5 steps of knowledge pursue, which were 1) determine the objective of knowledge pursue, 2) plan for knowledge pursue, 3) process the knowledge pursue, 4) analyze the data acquired from knowledge pursue, and 5) summarize the acquired knowledge. When the learner gained sufficient knowledge for creating innovation to resolve problem, moved to step 3.

Step 3 Develop. To develop the innovation to resolve problem based on the acquired knowledge from Step 2. The innovation for resolving problem might be the thinking method, practice or invention which was different from the traditional concept, method or 
invention. The leaning was the cycle of innovation development which comprised of 4 steps: Plan, Do, Check, and Reflection. The essence of each step was as follows.

Plan The learner planned the innovation creation to resolve problem by applying knowledge to set a plan which consisted of the objective, process, equipment (if any), and evaluation. Then, the learner evaluated the possibility of plan implementation and the worthiness.

Do The learner created the innovation based on the plan. While creating the innovation, the learner also applied the knowledge acquired from knowledge pursue if more knowledge was required. The learner tried out the created innovation and collected the result with different methods systematically.

Check To analyze the compiled data to examine and evaluate if the created innovation could resolve the problem or not.

Reflect To deliberate the analysis results and conclude that the created innovation resolves the problem or not and why, and consider the strengths of the innovation to be maintained and the weakness to be improved. Such the weakness would lead to the 2 nd cycle.

\section{4) Media and learning source}

To use the media and the learning sources at school, home or in the community as well as the online media or sources, and person or wisdom which appropriate to the problem that the learner would like to develop the innovation.

\section{5) Evaluation and feedback}

It was to evaluate by observing the creative and innovation skills of the learner individually or as a group. The scoring criteria based on the authentic assessment; evaluated along with doing the activity of the learner. The feedback was given via the encouragement, self-confidence strengthening, and the advices to the learner to apply the efficient thinking and learning process.

The learning management model for creative and innovation skills enhancement was showed as the following figure.

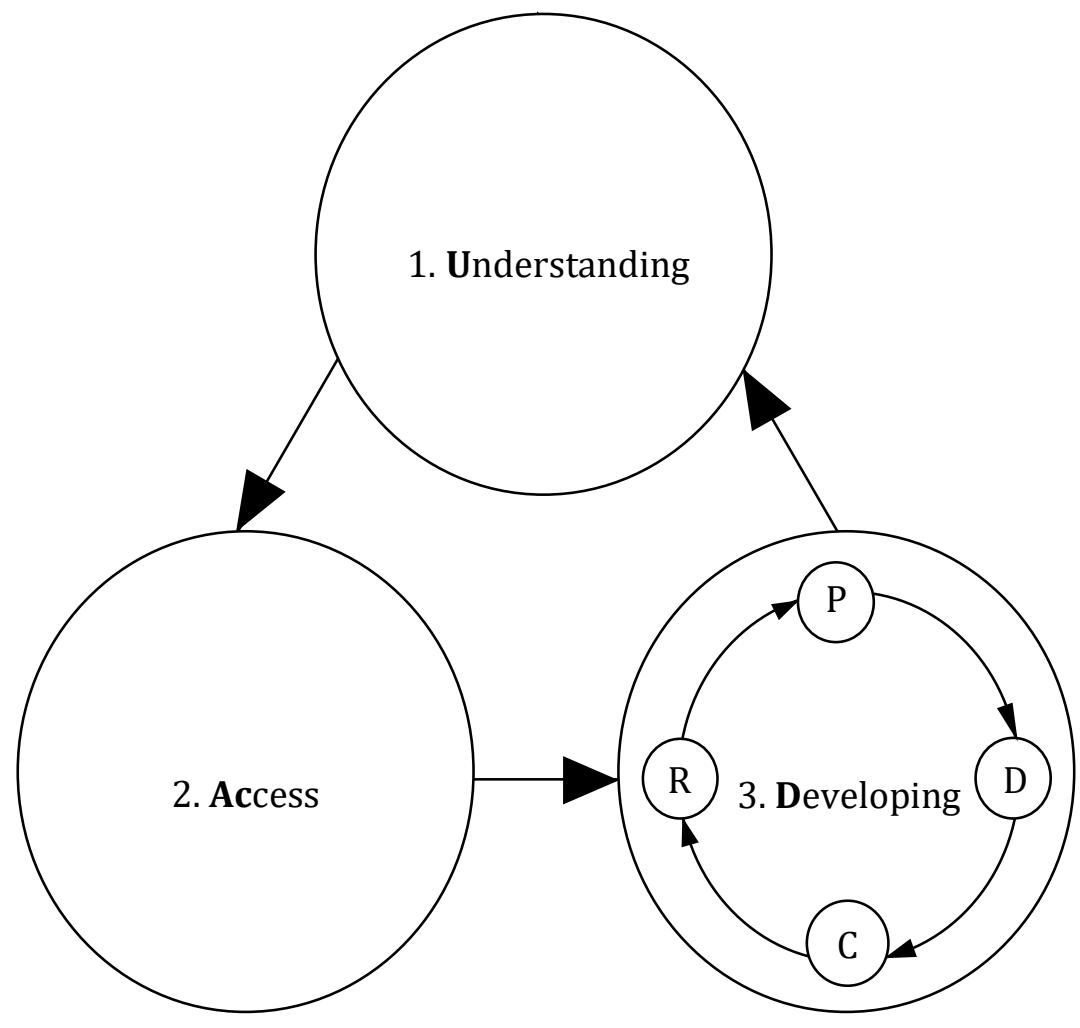

Figure 3. The "UAcD" Model 


\section{Evaluation result of the effectiveness of learning management model for creative and innovation skills enhancement}

The analysis results of creative and innovation skills, twice before the implementation, 4 times during the implementation, and twice after the implementation every 2 weeks, was as follows.

Table 1. Evaluation results of the effectiveness of the learning management model for creative and innovation skills enhancement

\begin{tabular}{|c|c|c|c|c|c|c|c|c|}
\hline \multirow{2}{*}{ Statistics } & \multicolumn{8}{|c|}{ Period of creative and innovation skills evaluation (Total score $=25$ ) } \\
\hline & $\begin{array}{c}\text { Before } \\
1^{\text {st }}\end{array}$ & $\begin{array}{l}\text { Before } \\
2^{\text {nd }}\end{array}$ & $\begin{array}{c}\text { During } \\
3^{\text {rd }}\end{array}$ & $\begin{array}{l}\text { During } \\
4^{\text {th }}\end{array}$ & $\begin{array}{l}\text { During } \\
5^{\text {rd }}\end{array}$ & $\begin{array}{l}\text { During } \\
6^{\text {th }}\end{array}$ & $\begin{array}{l}\text { After } \\
7^{\text {th }}\end{array}$ & $\begin{array}{l}\text { After } \\
9^{\text {th }}\end{array}$ \\
\hline $\bar{X}$ & 10.57 & 11.07 & 13.14 & 15.07 & 19.21 & 21.07 & 20.86 & 20.50 \\
\hline SD & 0.85 & 0.83 & 0.86 & 0.62 & 0.97 & 1.07 & 1.17 & 1.34 \\
\hline $\begin{array}{c}\text { \% of } \\
\text { total score }\end{array}$ & $42.48 \%$ & $44.28 \%$ & $52.56 \%$ & $60.28 \%$ & $76.84 \%$ & $84.28 \%$ & $83.44 \%$ & $82.00 \%$ \\
\hline $\begin{array}{c}\text { \% of } \\
\text { Increase/ } \\
\text { Decrease } \\
\text { from the } \\
\text { previous } \\
\text { evaluation }\end{array}$ & - & $\begin{array}{l}\text { Increase } \\
4.73 \%\end{array}$ & $\begin{array}{c}\text { Increase } \\
18.70 \%\end{array}$ & $\begin{array}{c}\text { Increase } \\
14.69 \%\end{array}$ & $\begin{array}{l}\text { Increase } \\
24.47 \%\end{array}$ & $\begin{array}{c}\text { Increase } \\
9.68 \%\end{array}$ & $\begin{array}{c}\text { Decrease } \\
1.00 \%\end{array}$ & $\begin{array}{l}\text { Decrease } \\
1.73 \%\end{array}$ \\
\hline
\end{tabular}

The table showed that the student creative and innovation before model implementation, evaluated twice every 2 weeks, was at 42.48 and $44.28 \%$ of the total score. The percentage during model implementation, evaluated 4 times every 2 weeks was $52.56,60.28,76.84$, and $84.28 \%$ of the total score, which increased during the period and be consistent with the effectiveness criteria. After model implementation, the student creative and innovation skills, evaluated twice every 2 weeks, was 83.44 and $82.00 \%$ of the total score.

\section{DISCUSSION and CONCLUSIONS}

Research results indicated that the learning management model for creative and innovation skills enhancement "UAcD" model was the effective model that responded to the demand for learning management. It prepared the learner to enter the world of career in the near future where the creativity and innovation was very crucial. This was because the future world would full of disruptive innovation (King, \& Baatartogtokh, 2018). Therefore, the learning in the new era should develop the learner to be able to create the innovation (Markham, 2016) via learning by doing (Ritchhart, Church, \& Morrision, 2011) and give significance to the learning process that would lead to the knowledge construction by oneself, which was the vital basis of the innovation creation (Hein, 1991).

Learning process of "UAcD" model consisted of 3 steps based on the work principle of the King Rama IX, "Understanding, Access and Develop" which focused on the learning process that was consistent with the nature and the information accessibility to create the innovation to truly fulfill the demand. The innovation development was constructed with knowledge and wisdom, tried out and improved for the sustain outcome (Thailand Sustainable Development Foundation, 2018).

The first step of learning process component was "Understanding" which was the significant step for innovation creation because it made the learner to have an insight of the problem in order to know the root cause of problem, which might have single or multiple related causes. Such understanding was the basement of the knowledge pursue and innovation creation 
afterwards. Therefore, this step emphasized on the problem analysis to have the insight. As Ellison and Hayes stated that learning, which led to the innovation creation, was the learning that constructed deep understanding (Ellison, \& Hayes. 2009). Moreover, Erickson, Lanning, and French stated that the learner should have a true understanding in order to create the innovation (Erickson, Lanning, \& French, 2017). The instructor should encourage the learner to use the analysis thinking to understand the problem clearly (Hildrew, 2018).

The second step was "Access" which allowed the learner to have the accurate, clear and sufficient knowledge to crate the innovation to solve the problem. Scott explained that learning to be prepared for the future should emphasize on the concept (Scott, 2015) which was the factor for creating the innovation successfully and efficiently. The acquired knowledge from this step would be the core concept because it would connect and be synthesized to the innovative idea. As Blackburn stated that the learner should have a mastery learning before applying knowledge to create the innovation (Blackburn, 2016). It was to say that the deep learning was applied to crate the innovation. Further, Knight stated that the learning would navigate the learner to create the innovation if he had the deep understanding (Knight, 2018). It was in line with Markham who stated that in order to create the innovation, learning should focus on the concept (Markham, 2016). Furthermore, OECD pointed out that to have the efficient learning, the learner should understand the content or the accurate and insight knowledge to connect and invent the innovation (OECD, 2018b). Self-knowledge pursue was the practice to assist the learner to be selfreliant on learning and to respond to the learning in the new era. Markham stated that learning in the new era must allow the learner to pursue knowledge by themselves (Markham, 2016). It was very important that the instructor gave an opportunity to the learner to have self-learning (The Economist, 2017). Besides, the information technology was utilized to seek for modern knowledge to fulfill the learning method of the learner individually. As the Office of Educational Technology stated that the learning management that best motivated the learner to pursue knowledge should respond to the individual learner demand with the support of the information technology (Office of Educational Technology, 2016). Similarly, Pearson Cooperation mentioned that the learner should apply technology as a tool to access knowledge (Pearson Cooperation, 2017) which was quite open for the learners to learn by themselves using technology to promote the innovative concept efficiently.

The final step was "Develop" which the learner was able to create the innovation successfully followed the 4 steps including Plan, Do, Check, and Reflect. This was the systematic and efficient learning process that assisted the learner to do the activities followed the appropriate step. As Gill and Thompson stated that the instructor should design the learning activity as the learner-based activity (Gill, \& Thomson, 2017) and the learner should apply the learning process to accomplish the goal (Bloomberg, \& Pitchford, 2017). Moreover, this step give a change to the learner to utilize their own learning method to invent the innovation to respond to the individual differences. World Economic Forum stated that the learning leading to the innovation invention should respond to the learning approach of the learner in the new era and give the space to the learner to develop their potential (World Economic Forum, 2018). Further, Forgaty mentioned that in the actual learning, the instructor could not learn for the learner or force them to learn. On the other hand, the instructor must design the learning activity to allow the learner to do it by themselves via the quality learning process (Fogarty, 2016). Besides, the instructor evaluated the learner constantly based on the authentic assessment and provided the useful feedback to promote the innovation creation process of the learner. Gregory and Kaufeldt indicated that the instructor had to evaluate and provide the feedback to the learner for the continuing improvement (Gregory, \& Kaufeldt, 2015), accurate and quick learning (Greenstein, 2012).

The results of the research concluded that the teaching model named "UAcD" model can effectively improve the innovation skills of elementary school students. The strengthen of the "UAcD" model was a learning management cycle from the understanding step to access step and developing step. Future more, in the developing step there were a learning cycle for creative and innovation enhancement named PDCR. The PDCR was the most important of students' improvement because the students have the opportunity to continuously create innovations 
based on their interests. In addition, the characteristics of "UAcD" model based on the active learning approach that provide learning activities for students according to Seechaliao (2017) found that using a variety of stimulating ideas to find possible solutions to the problems facilitates brainstorming and helps learners think about new ideas also using questions, classroom discussion, self-directed study, inductive and deductive thinking, media or social media make students engage in learning activities and create innovation in learning, Sadykova, Semenyuk, Khvan, \& Kuc (2016) found that architechural workshops can be improve students' creative and innovation skills, Miranti, \& Wilujeng (2017) found that using mind mapping and Ritter \& Mostert (2017) found that Cognitive-Based Creativity Training can be improve creative and innovation skills, and Rahmawati, Ridwan, Hadinugrahaningsih, \& Soeprijanto (2018) found that using STEM model for instruction can develop students' creative and innovation skills. However, the weakness of this study was the small sample size in the implementation step. Having a small sample size may affect the ability to summarize references to other samples. Therefore, the use of the model may need to be adjusted to suit the context of learning management, for example students' learning style, age of students, subject matter. However, implication the "UAcD" model still follow the steps outlined in the "UAcD" model.

Recommendation for results application were 1) Learning management should follow the full step of the model as the previous step is the key base of the following one. Moreover, ongoing learning is essential, 2) The teacher has the roles to motivate and encourage the learner, point out the awareness of self-value to offer the benefits for the community since innovation creation arises from a public mind, and 3) Regarding the evaluation, the teacher should apply the assessment for learning and offer the student the opportunity to have self-assessment to navigate and improve the learning process (assessment as learning), as well as the innovation creation process. Recommendations for further researches should be extended or further developed to respond to the demand for diverse innovations according to the different social context and cultures. It might be the innovation of wisdom, food, handicraft, or other areas.

\section{REFERENCES}

Abdulla, A. (2017). Coaching Students in Secondary Schools: Closing the Gap Between Performance and Potential. New York, NY: Routledge.

Adams, K. (2005). The Sources of Innovation and Creativity. Washington D.C.: National Center on Education and Economy.

Anderson, L. W. \& Krathwohl, D. R., et al (Eds..) (2001). A Taxonomy for Learning, Teaching, and Assessing: A Revision of Bloom's Taxonomy of Educational Objectives. Boston: Allyn \& Bacon.

Bell, S. (2010). Project - Based Learning for the 21st Century: Skills for the Future. The Clearing House, 8(3), 39-43. DOI: $10.1080 / 00098650903505415$

Blackburn, R. B. (2016). Motivating Struggling Learners: 10 Ways to Build Student Success. New York, NY: Routledge.

Bloomberg, P., \& Pitchford, B. (2017). Leading Impact Teams: Building a Culture of Efficacy. Thounsand Oaks, CA: Corwin.

Department of Education, Employment and Workplace Relations. (2009). Developing Innovation Skills: A Guide for Trainers and Assessors to Foster the Innovation Skills of Learners through Professional Practice. Wellington: Innovation \& Business Skills Australia.

Dewey, J. (1934). The Art of Experience. New York, NY: Capricorn Books.

Ellison, J., \& Hayes, C. (2009). Cognitive coaching: Weaving Threads of Learning and Change into the Culture of an Organization. Norwood, MA: Christopher-Gordon.

Erickson, H. L., Lanning, L. A., \& French, R. (2017). Concept-Based Curriculum and Instruction for the Thinking Classroom (2nd. ed.). Thounsand Oaks, CA: Corwin.

Fogarty, J. R. (2016). Invite Excite Ignite: 13 Principles for Teaching, Learning, and Leading, K-12. New York, NY: Teachers College Press.

Gill, S., \& Thomson, G. (2017). Human-Centred Education: A Practical Handbook and Guide. New York, NY: Routledge.

Greenstein, L. (2012). Assessing 21st Century Skills: A Guide to Evaluating Mastery and Authentic Learning. Thousand Oaks, CA: Corwin. 
Gregory, G., \& Kaufeldt, M. (2015). The Motivated Brain: Improving Student Attention, Engagement, and Perseverance. Alexandria, VA: ASCD.

Griffith University. (2011). Creative and Innovation Toolkit. 2nd. International Society for Technology in education. (online) www.iste.org/standards.

Guilford, J. P. 1988). Some Changes in the Structure of Intellect Model. Educational and Psychological Measurement, 4(8), 1-4.

Hein, G. E. (1991). Constructivist Learning Theory, CECA (International Committee of Museum Educators) Conference, Retrieved August 20, 2018, from https://www.exploratorium.edu/education/ifi/constructivist-learning

Hildrew, C. (2018). Becoming A Growth Mindset School: The Power of Mindset to Transform Teaching, Leadership and Learning. New York, NY: Routledge.

Hondzel, C. D. (2013). Fostering Creativity: Ontario Teacher's Perceptions, Strategies, and Experiences. London: Graduate Program in Education Studies.

King, A. A. \& Baatartogtokh, B. (2018). How Useful Is the Theory of Disruptive Innovation? MITSloan Management Review, 57(1), 77-90.

Knight, J. (2018). The Impact Cycle: What Instructional Coaches Should Do to Foster Powerful Improvements in Teaching. Thousand Oaks, CA: Corwin.

Levin, J. R., Marascuilo, L. A., \& Hubert, L. J. (1978). N = Nonparametric Randomization Tests. In T. R. Kratochwill (Eds.), Single Subject Research:Strategies for Evaluating Change (167-196). New York: Academic Press.

Markham, T. (2016). Redefining Smart Awakening Student's Power to Reimagine Their World. Thousand Oaks, CA: Corwin.

McGinn, A. (2007). Senior High School Education in the 21st Century. The Educational Forum, 71(4), 331 344.

Miranti, M. G., Wilujeng, B. Y.. (2017). Creative Thinking Skills Enhancement Using Mind Mapping. Advances in Social Science, Education and Humanities Research (ASSEHR), 112, 39-42.

Nieuwerburgh, C. V. (2017). An Introduction to Coaching Skills: A Practical Guide (2nd ed.). Thousand Oaks, CA: SAGE Publications.

OECD. (2018a). PISA: Preparing Our Youth for an Inclusive and Sustainable World the OECD PISA Global Competency Framework. Paris: Organisation for Economic Co-operation and Development

OECD. (2018b). The Future of Education and Skills Education 2030. Paris: Organisation for Economic Cooperation and Development

Office of Educational Technology. (2016). Future Ready Learning: Reimaging the Role of Technology in Education. Washington, D.C.: U.S. Department of Education.

Partnership for 21st Century Skills. (2011). Professional Development: A 21st Century Skills Implementation Guide. Tucson: Partnership for 21st century skills Organization.

Pearson cooperation. (2017). The Future of Learning: Pearson Annual Report and Accounts 2017. New York, NY: Pearson.

Rahmawati, T., Ridwan, A., Hadinugrahaningsih, T., \& Soeprijanto. (2018). Developing Critical and Creative Thinking Skills through STEAM Integration in Chemistry Learning. International Conference of Chemistry (ICCHEM), 1-7.

Ritter, S. M. \& Mostert, N. (2017). Enhancement of Creative Thinking Skills Using a Cognitive-Based Creativity Training. J Cogn Enhanc, 1, 243-253 DOI 10.1007/s41465-016-0002-3

Ritchhart, R. Church, M., \& Morrision, K. (2011). Making Thinking Visible: How to Promote Engagement, Understanding, and independence for All Learners. San Francisco, CA: Jossey-Bass.

Rotherham, A. J. \& Willingham, D. T. (2010). 21st Century Skills Not New but Worthy Challenge. American Educator. Spring: $17-20$.

Saavedra, A. Rosefsky. \& Opfer, V. Darleen. (2012). Teaching and learning 21st Century Skills: Lessons from the Learning Science. Asia Society Partnership for Global Learning: RAND corporation.

Sadykova, S., Semenyuk, O., Khvan, E. \& Kuc, S. (2016). Development of Students' Creative Skills through Architectural Workshops. Global Journal of Engineering Education, 18(3), 223-231.

Scott, C. L. (2015). The Future of Learning 2: What Kind of Learning for the 21stCentury? Paris: United Nations Educational, Scientific and Cultural Organization.

Seechaliao, T. (2017). Instructional Strategies to Support Creativity and Innovation in Education. Journal of Education and Learning, 6(4), 201-208.

Sweeney, D. \& Mausbach, A. (2018). Leading Student-Centered Coaching: Building Principal and Coach Partnership. Thousand Oaks, CA: Corwin.

The Economist. (2017). Special Report Lifelong Education: Learning and Learning. Retrieved August 20, 2018, from https://www.economist.com/sites /default/files/learning_and_earning.pdf 
Torrance, E. P. (1977). Creativity in the Classroom: What Research Says to the Teacher. Washington, D.C.: National Education Association.

UNESCO. (2018). Building Tomorrow's Digital Skills: What Conclusions Can We Draw from International Comparative Indicator? Paris: United Nations Educational, Scientific and Cultural Organization.

Williams, F. E. (Dec 1969). Models for Encouraging Creativity in the Classroom by Integrating CognitiveAffective Behaviors. Educational Technology, 9(12), 7-13.

World Economic Forum. (2016). The Future of Jobs: Employment, Skills and Workforce Strategy for the Fourth Industrial Revolution. Geneva: World Economic Forum.

World Economic Forum. (2018). Eight Futures of Work: Scenarios and Their Implications. Geneva: World Economic Forum. 